\title{
Does the Type of Material Information Matter to CEO Turnover?
}

\author{
Ya-Fang Wang \\ Department of Accounting, Providence University \\ 200, Sec. 7, Taiwan Boulevard, Shalu Dist., Taichung City 43301 Taiwan (R.O.C.) \\ Tel: 886-4-2632-8001 ext.13216_E-mail: yfwang2@pu.edu.tw
}

Received: Feb. 20, 2016 Accepted: May 6, $2016 \quad$ Published: June 1, 2016

doi:10.5296/ajfa.v8i1.9339 URL: http://dx.doi.org/10.5296/ajfa.v8i1.9339

\begin{abstract}
Using hand-collected data to obtain the nature of material information, I examine whether and how the likelihood of CEO turnover is associated with material information disclosures. I find the likelihood of CEO turnover increases following different types of material information announcements. Further, I partitioned the sample into the various stages of company life cycle in order to determine whether life cycle stage affects the relationship between the disclosure of material information and CEO turnover. The results show that the disclosure of material information by companies only in maturity and decline is associated with high CEO turnover.
\end{abstract}

Keywords: Material information, CEO turnover 


\section{Introduction}

Issuing material information is a people-oriented corporate culture in which product safety and consumer rights are paramount. Hence, encouraging companies to issues material information is particularly important, because such companies of issuing material information are more likely to reject illegal act when they face the beneficial temptation. One key to sustainable operations is to bear in mind material information in the full weight of any corporate decision. Companies are more likely to disclose material information when they think such information is important to corporate decisions and are therefore more likely to win trust and respect from customers and stockholders. In this study, I focus on whether material information disclosures are associated with following economic consequences, because I argue that the nature of material information disclosures is of particular importance and may cause various influences on companies and market participants (Foster and Viswanathan 1993; Kim and Verrecchia 1991; Holthausen and Verrecchia 1988). Material information disclosures belong to voluntary disclosures in Taiwan, and Taiwan has specific sections designated to encourage companies to disclose material information in a timely and accurate manner.

Material information is defined as (1) financial or nonfinancial information having a material impact on a public company's financial and business performance, or (2) financial or nonfinancial information having a material impact on the price of the securities or investment decision of market participants. According to the laws stated in the Taiwan Stock Exchange Corporation Procedures, material information can be classified into six categories to capture the nature of material information from different perspectives. According to the Taiwan Stock Exchange Corporation Procedures for Verification and Disclosure of Material Information of Companies with Listed Securities, I divided the disclosure of material information into six classifications: (1) material change in shareholder equity, (2) material change in business policy, (3) material disasters resulting in serious reduction or complete cessation of production, (4) material effects on shareholder equity or company operations resulting from a change in laws, regulations, or rules of the home country, (5) mass media reportage about the parent company sufficient to affect securities prices of a listed subsidiary in the ROC, and (6) occurrence of any other material event that shall be immediately reported pursuant to law or regulation of a foreign company's home country.

Although prior studies show that voluntary disclosures provided have the potential to reveal incremental information (Bushee and Goodman 2007; Al-Tuwaijri et al. 2004; Orlitzky et al. 2003; Margolis and Walsh 2001) and these disclosures can affect firms' performance (Dhaliwal et al. 2011; Cohen et al. 2011; Cruise 2011; Lev et al. 2010; CICA survey 2010; Rodríguez et al. 2006; Gelb and Strawser 2001), there is yet systematic evidence on the association between material information disclosures and following economic consequences. Particularly a series of food safety scandals (e.g., Chang Chi Foodstuff Factory Co., Flavor Full Food Inc. and Ting Hsin International Group) led many to pay attention to the competence of companies and the importance of material information disclosures. Additionally, Iatridis and Alexakis (2012) further find that corporate disclosures are a more reliable reflection of a firm's financial health. Hence, material information disclosures can 
interpret as signals of firms' financial health. This raises the question of whether companies are likely to terminate their CEOs when they think the CEO shall be responsible for material information disclosures.

The remainder of this study is organized as follows: Section 2 presents a literature review. Section 3 describes the sample selection process and research design. Section 4 reports the empirical results. Conclusions are discussed in Section 5.

\section{Literature Review}

According to Furtado and Karen (1990), the research on executive turnover comprises three broad categories: (1) factors contributing to turnover, (2) immediate market reactions to executive turnover events, and (3) subsequent performance post management turnover. Many studies on executive turnover change the focus from poor performance to financial reporting quality. And, these empirical studies have proved the existence of the relationship between poor performance and the likelihood of managerial turnover (Coughlan and Schmidt 1985; Warner et al. 1988; Weisbach 1988; Denis et al. 1997; Engel et al. 2003; Bonnier and Bruner 1989; Furtado and Rozeff 1987; Kaplan and Minton 2006; Kim 2008; Karpoff et al. 2008). In this study, I focus on whether material information disclosures are associated with following executive turnover, because I argue that the nature of material information disclosures is of particular importance and may cause various influences on companies and market participants (Foster and Viswanathan 1993; Kim and Verrecchia 1991; Holthausen and Verrecchia 1988). Thus, my study represents initial attempt to reveal the intricacy between executive turnover and material information.

Corporate disclosures can reduce inefficiency in the market and identified the factors underlying the motives of mangers in the voluntarily disclosure of information (Lambert et al. 2007; Core 2001; Healy and Palepu 2001; Diamond and Verrecchia 1991), and these disclosures are associated with management incentives (Merkley 2014; Kravet and Muslu 2013; Davis et al. 2012; Price et al. 2012; Loughran and McDonald 2011; Henry 2008; Li 2006). Some studies (Desai et al. 2006; Arthuad-Day et al. 2006; Burks 2010; Collins et al. 2009) further reported that companies of issuing material information generally experience a series of turmoil, including negative publicity, difficulty in accessing capital markets, decrease in stock price, lawsuits, and potential enforcement by the Securities and Exchange Commission. Despite the growing importance of information regarding firms' voluntarily disclosures to executive turnover, evidence on its role in responsible behavior of information disclosures is scant. In particular, there is little evidence on whether information about executive turnover conveyed through material information provides incremental information to investors by reducing uncertainty. Therefore, I examine whether companies are more likely to terminate their CEOs following material information announcements, because material information matters to the market, and assessments of disclosing behavior can potentially provide useful and timely information to investors. When a company issues its relevance information through the disclosure of material information, market participants may interpret executive turnover following disclosing decisions as responsible behavior. 


\section{Research Design}

\subsection{Data Sources}

To test research questions, I collected publicly listed companies in Taiwan over the period from 2007 to 2012. My sample comprised 7,777 firm-year observations and this sample was identified through two sources. I began by hand collecting data related to types of MI disclosures from the Market Observation Post System. I then accessed company-level data related to CEO turnover and accounting from the Taiwan Economic Journal (TEJ) database. Table 1 provides the distribution of research samples across industries and years and shows that electronics industry has the highest percentages in research samples $(61.87 \%)$, while cement industry has the lowest percentages in research samples $(0.46 \%)$.

Table 1. Sample Distribution

\begin{tabular}{lccccccc}
\hline Industry & 2007 & 2008 & 2009 & 2010 & 2011 & 2012 & Total \\
\hline Chemicals & 76 & 78 & 80 & 81 & 86 & 88 & 489 \\
Cement & 6 & 6 & 6 & 6 & 6 & 6 & 36 \\
Glass \& Ceramics & 12 & 12 & 12 & 12 & 12 & 12 & 72 \\
Constructions & 70 & 69 & 69 & 70 & 69 & 70 & 417 \\
Food & 24 & 24 & 24 & 24 & 25 & 25 & 146 \\
Textile & 54 & 54 & 54 & 54 & 53 & 54 & 323 \\
Transportations & 24 & 23 & 23 & 23 & 24 & 24 & 141 \\
Trading & 22 & 22 & 22 & 22 & 22 & 22 & 132 \\
Plastic & 25 & 25 & 25 & 26 & 26 & 26 & 153 \\
Electronics & 780 & 789 & 798 & 805 & 818 & 822 & 4,812 \\
Appliance \& Cable & 15 & 16 & 17 & 18 & 18 & 18 & 102 \\
Electric \& Machinery & 67 & 68 & 68 & 71 & 75 & 75 & 424 \\
Tourism & 19 & 20 & 20 & 20 & 19 & 19 & 117 \\
Others & 65 & 65 & 65 & 69 & 74 & 75 & 413 \\
\hline Total & 1,259 & 1,271 & 1,283 & 1,301 & 1,327 & 1,336 & 7,777 \\
\hline
\end{tabular}

\subsection{Model Specification -Material Information vs. CEO Turnover}

I constructed a research model to explore whether material information is associated with CEO turnover, and test which types of material information can better describe companies' reactions to releases of material information. The research model (1) is as follows:

$$
C E O=\alpha_{0}+\alpha_{1-6} M I+\alpha_{2} R O A+\alpha_{3} L O S S+\alpha_{4} L E V+\alpha_{5} S I Z E+\alpha_{6} G C O+\varphi \mathrm{YEAR}+\varepsilon_{i, t}
$$

where CEO equals 1 if the CEO leaves the company following the material information, else $0 ; M I-1$ equals 1 if the company disclosed material change in shareholder equity, else $0 ; M I-2$ 
equals 1 if the company disclosed material change in business policy, else $0 ; M I-3$ equals 1 if the company disclosed material disaster resulting in serious reduction or complete cessation of production, else $0 ; M I-4$ equals 1 if the company disclosed material effect on shareholders' equity or company operations resulting from a change in laws, regulations, or rules of the home country, else 0; MI-5 equals 1 if the company disclosed mass media reportage about the parent company sufficient to affect securities prices of a listed subsidiary in the ROC, else 0 ; MI-6 equals 1 if the company disclosed occurrence of any other material event that shall be immediately reported pursuant to law or regulation of the foreign company's home country, else $0 ; R O A$ equals net income divided by total assets; LOSS equals 1 if operating income is less than zero, else 0; $L E V$ equals long-term debt divided by total assets; SIZE equals the natural $\log$ of total assets; GCO equals 1 if the company receives a going concern opinion, else 0; and YEAR equals dummy variables controlling for years.

\section{Results and Analysis}

Table 2 presents the descriptive statistics for all variables used in our research models, partitioned by two subsamples: cases of companies with CEO turnover $(n=1,089)$, and cases without CEO turnover $(\mathrm{n}=6,688)$. As such, comparing two subsamples provides evidence as to whether or not CEO turnover is more likely to be associated with types of material information. The means (medians) of $M I-1, M I-2$ and $M I-4$ reported in the subsample with CEO turnover are at the 0.01 level for both tests, which is significantly larger than those reported in the subsample with no CEO turnover. In addition, the means (medians) of LOSS and GCO reported in the CEO turnover subsample are at the 0.01 level for both tests, which is significantly larger than those reported in the subsample without CEO turnover. The means (medians) of ROA and SIZE reported in the CEO turnover subsample are at the 0.01 level for both tests, which is significantly smaller than those reported in the subsample without CEO turnover. Univariate comparisons indicate that companies of CEO turnover have high more material information ( $M I-1, M I-2, M I-4)$, perform bad (ROA) and suffer more losses (LOSS), receive more going-concern opinions (GCO), and are smaller in size (SIZE) than companies without CEO turnover. Overall, my findings suggest that material information is likely to be associated with CEO turnover. 
Table 2. Descriptive Statistics

\begin{tabular}{|c|c|c|c|c|c|c|}
\hline \multirow[b]{2}{*}{ Variables } & \multicolumn{2}{|c|}{$\begin{array}{l}\text { CEO turnover } \\
\quad(\mathrm{n}=1,089)\end{array}$} & \multicolumn{2}{|c|}{$\begin{array}{c}\text { No CEO turnover } \\
\quad(n=6,688)\end{array}$} & \multirow[t]{2}{*}{$\mathrm{t}$-test ${ }^{1}$} & \multirow[t]{2}{*}{ Wilcoxon } \\
\hline & Mean & Median & Mean & Median & & \\
\hline$M I-1$ & 0.672 & 1.000 & 0.608 & 1.000 & $4.028 * * *$ & $4.024 * * *$ \\
\hline MI-2 & 0.914 & 1.000 & 0.859 & 1.000 & $4.895 * * *$ & $4.888^{* * *}$ \\
\hline MI-3 & 0.031 & 0.000 & 0.029 & 0.000 & 0.374 & 0.374 \\
\hline$M I-4$ & 0.803 & 1.000 & 0.768 & 1.000 & $2.577 * * *$ & $2.576^{* * *}$ \\
\hline MI-5 & 0.490 & 0.000 & 0.481 & 0.000 & 0.591 & 0.591 \\
\hline$M I-6$ & 0.021 & 0.000 & 0.020 & 0.000 & 0.269 & 0.269 \\
\hline$R O A$ & 0.004 & 0.025 & 0.042 & 0.045 & $-10.520 * * *$ & $-9.769 * * *$ \\
\hline LOSS & 0.347 & 0.000 & 0.208 & 0.000 & $10.236^{* * *}$ & $10.169^{* * *}$ \\
\hline$L E V$ & 0.076 & 0.027 & 0.069 & 0.026 & $2.067^{* *}$ & 1.067 \\
\hline SIZE & 15.027 & 14.814 & 15.212 & 15.027 & $-3.866 * * *$ & $-4.465 * * *$ \\
\hline$G C O$ & 0.035 & 0.000 & 0.011 & 0.000 & $6.268 * * *$ & $6.253 * * *$ \\
\hline
\end{tabular}

${ }^{1}$ Asterisks $*, * *, * * *$ indicate significance at the $0.10,0.05$, and 0.01 levels.

Table 3 represents the Pearson correlation for all variables used in the research models. Results show that CEO is positively correlated with MI-1 (0.046), MI-2 (0.055), and MI-4 (0.029), implying that companies with material information releases are more likely to terminate their CEO. CEO was also shown to be correlated with ROA (-0.019), LOSS (0.115), LEV (0.023), SIZE (-0.044), and GCO (0.071), suggesting that smaller companies, bad performance, unfavorable audit opinion, and those with more pronounced losses and higher leverage, were more strongly associated with CEO turnover. As depicted in this table, most explanatory variables are not significantly correlated to each other. I also estimate variance inflation factors (VIFs) to test for possible multicollinearity while considering all independent and control variables. None of the VIFs is greater than 1.7, indicating no presence of multicollinearity in my study. 
Table 3. Correlation Matrix

\begin{tabular}{|c|c|c|c|c|c|c|c|c|c|c|c|}
\hline $\begin{array}{l}\text { Variables } \\
1\end{array}$ & $\begin{array}{l}M I- \\
1\end{array}$ & $\begin{array}{l}M I- \\
2\end{array}$ & $\begin{array}{l}M I- \\
3\end{array}$ & $M I-4$ & $M I-5$ & $M I-6$ & $R O A$ & LOSS & $L E V$ & SIZE & $G C O$ \\
\hline CEO & $\begin{array}{l}0.046 \\
*\end{array}$ & $\begin{array}{l}0.055 \\
*\end{array}$ & 0.004 & $0.029^{*}$ & 0.007 & 0.003 & $-0.119^{*}$ & $0.115^{*}$ & $0.023^{*}$ & $-0.044^{*}$ & $0.071^{*}$ \\
\hline MI-1 & & $\begin{array}{l}0.147 \\
*\end{array}$ & 0.007 & $0.098^{*}$ & $\begin{array}{l}0.160 \\
*\end{array}$ & 0.022 & -0.018 & 0.016 & $0.073^{*}$ & $0.142^{*}$ & $0.045^{*}$ \\
\hline MI-2 & & & 0.012 & 0.006 & $\begin{array}{l}0.111 \\
*\end{array}$ & 0.016 & -0.019 & -0.006 & $0.078^{*}$ & $0.152^{*}$ & -0.020 \\
\hline MI-3 & & & & -0.022 & $\begin{array}{l}0.036 \\
*\end{array}$ & 0.013 & 0.004 & -0.004 & $0.037^{*}$ & $0.048^{*}$ & -0.002 \\
\hline$M I-4$ & & & & & $\begin{array}{l}0.099 \\
*\end{array}$ & 0.021 & $0.030^{*}$ & $-0.040^{*}$ & $0.038^{*}$ & $0.094^{*}$ & -0.013 \\
\hline MI-5 & & & & & & $\begin{array}{l}0.044 \\
*\end{array}$ & $0.142^{*}$ & $-0.129^{*}$ & $0.100^{*}$ & $0.394^{*}$ & $-0.046^{*}$ \\
\hline MI-6 & & & & & & & $-0.041^{*}$ & 0.001 & 0.004 & $0.066^{*}$ & -0.009 \\
\hline$R O A$ & & & & & & & & $-0.600^{*}$ & $-0.103^{*}$ & $0.176^{*}$ & $-0.228^{*}$ \\
\hline LOSS & & & & & & & & & $0.115^{*}$ & $-0.181^{*}$ & $0.179^{*}$ \\
\hline$L E V$ & & & & & & & & & & $0.294^{*}$ & $0.048^{*}$ \\
\hline SIZE & & & & & & & & & & & $-0.131^{*}$ \\
\hline
\end{tabular}

$1 *$ Indicates significance at the 5 percent level.

Table 4 shows empirical evidence for companies of issuing material information are associated with higher rates of CEO termination. As predicted, the coefficient on MI-1, MI-2, MI-4, and MI-5 are significantly positive at least at the 0.05 significance level, suggesting material information involving (1) material change in shareholder equity, (2) material change in business policy, (3) material effect on shareholders' equity or company operations resulting from a change in laws, regulations, or rules of the home country, and (4) mass media reportage about the parent company sufficient to affect securities prices of a listed subsidiary in the ROC are more likely to terminate their CEOs following material information announcements. The coefficients on control variables (ROA, LOSS, SIZE, GCO) indicate that companies with better performance (ROA), fewer losses (LOSS), larger size (SIZE) and fewer unfavorable opinions (GCO) are associated with lower CEO turnover rates. 
Table 4. Material Information and CEO Turnover

\begin{tabular}{l|ccc}
\hline Variables & Pred. Sign & Coef. & -value $^{1}$ \\
CONSTANT & & -1.005 & $-4.65^{* * *}$ \\
MI-1 & $+/-$ & 0.089 & $2.30^{* *}$ \\
$M I-2$ & $+/-$ & 0.282 & $4.72^{* * *}$ \\
$M I-3$ & $+/-$ & 0.050 & 0.48 \\
$M I-4$ & $+/-$ & 0.128 & $2.87^{* * *}$ \\
$M I-5$ & $+/-$ & 0.082 & $2.09^{* *}$ \\
MI-6 & $+/-$ & -0.010 & -0.08 \\
ROA & - & -0.672 & $-3.98^{* * *}$ \\
LOSS & + & 0.254 & $5.12^{* * *}$ \\
LEV & + & 0.190 & 1.00 \\
SIZE & $+/-$ & -0.043 & $-3.02^{* * *}$ \\
GCO & + & 0.327 & $2.46^{* * *}$ \\
YEAR & & Included & \\
Pseudo $\mathrm{R}^{2}$ & & $3.05 \%$ & \\
Nobs. & & 7,777 & \\
\hline 1
\end{tabular}

${ }^{1}$ Asterisks $*, * *, * * *$ indicate significance at the $0.10,0.05$, and 0.01 levels, respectively. One-tailed for directional expectations, two-tailed for others.

Prior studies suggest that considering different stages of firm life cycle in marking decisions can improve the ability of managers to implement appropriate strategies, and to benchmark their performance (Hanks et al. 1993; Galbraith 1982). Thus, I partitioned the sample into the various stages of company life cycle in order to determine whether life cycle stage affects the relationship between the disclosure of material information and CEO turnover. Following prior studies (Black 1998; Anthony and Ramesh 1992), I first construct life cycle model that incorporates a firm's five-year history of four classification variables: age, sales growth, dividend yield, and capital expenditures. Second, I assign each firm-year scores based on their relative ranking of these four classification variables. Third, the scores for each of the four classification variables combine into a composite score categorizing each firm-year observation into one of the following three life cycle stages: (1) growth, (2) maturity, and (3) decline. Table 5 presents the results related to the association between material information and CEO turnover in different stages of a company's life cycle. Surprisingly, coefficients of material information were significant (at least at the 5\% significance level) only in companies in maturity and decline, which implies that the disclosure of material information by companies in maturity and decline is associated with high CEO turnover. On the contrary, none of coefficient of material information in growth subsample is significant. A possible reason underlying this finding is that growth companies may less likely to issue material information. 
Table 5. Material Information and CEO Turnover: Consider Life Cycle

\begin{tabular}{|c|c|c|c|c|c|c|c|}
\hline \multirow{3}{*}{$\begin{array}{l}\text { Variables } \\
\end{array}$} & \multirow[b]{3}{*}{ Pred. Sign } & \multirow{2}{*}{\multicolumn{2}{|c|}{$\frac{(1)}{\text { Growth }}$}} & \multirow{2}{*}{\multicolumn{2}{|c|}{$\frac{(2)}{\text { Maturity }}$}} & \multirow{2}{*}{\multicolumn{2}{|c|}{$\begin{array}{c}(3) \\
\text { Decline }\end{array}$}} \\
\hline & & & & & & & \\
\hline & & Coef. & $z$-value ${ }^{1}$ & Coef. & z-value & Coef. & z-value \\
\hline CONSTANT & & -1.572 & $-3.48 * * *$ & -0.621 & $-2.15 * *$ & -1.546 & $-3.04 * * *$ \\
\hline MI-1 & $+1-$ & -0.011 & -0.12 & 0.120 & $2.31^{* *}$ & 0.097 & 1.17 \\
\hline$M I-2$ & $+1-$ & 0.163 & 1.29 & 0.264 & $3.23^{* * *}$ & 0.468 & $3.68^{* * *}$ \\
\hline MI-3 & $+1-$ & 0.163 & 0.83 & 0.043 & 0.31 & -0.062 & -0.21 \\
\hline MI-4 & $+1-$ & 0.133 & 1.47 & 0.070 & 1.18 & 0.328 & $3.00^{* * *}$ \\
\hline MI-5 & $+1-$ & 0.083 & 1.00 & 0.055 & 1.03 & 0.169 & $1.91^{*}$ \\
\hline MI-6 & $+1-$ & 0.241 & 0.96 & -0.225 & -1.24 & 0.346 & 1.20 \\
\hline$R O A$ & - & -0.732 & -1.52 & -0.598 & $-3.12 * * *$ & -1.251 & $-1.80^{*}$ \\
\hline LOSS & + & 0.283 & $2.40^{* *}$ & 0.280 & $4.39^{* * *}$ & 0.068 & 0.52 \\
\hline$L E V$ & + & -0.284 & -0.76 & 0.379 & 1.49 & 0.405 & 0.80 \\
\hline SIZE & $+1-$ & 0.005 & 0.16 & -0.067 & $-3.47 * * *$ & -0.027 & -0.81 \\
\hline GCO & + & 0.500 & $1.40^{*}$ & 0.211 & 1.32 & 0.541 & 1.50 \\
\hline YEAR & & Included & & Included & & Included & \\
\hline Pseudo $\mathrm{R}^{2}$ & & $2.8 \%$ & & $3.56 \%$ & & $4.36 \%$ & \\
\hline Nobs. & & 1,765 & & 4,400 & & 1,612 & \\
\hline
\end{tabular}

${ }^{1}$ Asterisks $*, * *, * * *$ indicate significance at the $0.10,0.05$, and 0.01 levels, respectively. One-tailed for directional expectations, two-tailed for others.

\section{Conclusions}

This study provides empirical evidence to explore whether material information is associated with CEO turnover based on a sample of 7,777 observations from 2007 to 2012. Overall, evidence shows that companies are more likely to terminate their CEOs following material information announcements. I further consider the various stages of company life cycle in order to determine whether life cycle stage affects the relationship between the disclosure of material information and CEO turnover. Notably, I find that the disclosure of material information by companies only in maturity and decline is associated with high CEO turnover.

One major limitation of this study is that approximately $99 \%$ of companies in Taiwan discloses material information, indicating that material information disclosures are a very common phenomenon in Taiwan. A possible reason underlying this finding is that material information disclosures in Taiwan are voluntary disclosures and Taiwan's government encourages companies to disclose material information with respect to the public interest. Thus, the skewness of material information disclosures may cause misspecification when this skewness in the dependent variable of Eq. (1). Future research can explore whether and how material information announcements can improve information transparency. 


\section{References}

Al-Tuwaijri, S. A., T. E. Christensen, \& K. E. Hughes II. (2004). The relations among environmental disclosure, environmental performance, and economic performance: A simultaneous equations approach. Accounting, Organizations and Society, 29(5-6), 447-471. http://dx.doi.org/10.1016/S0361-3682(03)00032-1

Anthony, J., \& K. Ramesh. (1992). Association between accounting performance measures and stock prices: A test of the life cycle hypothesis. Journal of Accounting and Economics, 15(2-3), 203-227. http://dx.doi.org/10.1016/0165-4101(92)90018-W

Arthaud-Day, M.L., Certo, S.T., Dalton, C.M., \& Dalton, D.R. (2006). A changing of the guard: executive and director turnover following corporate financial restatements. Academy of Management Journal, 49, 1119-1136. http://dx.doi.org/10.5465/AMJ.2006.23478165

Black, E. (1998). Life-cycle impacts on the incremental value-relevance of earnings and cash flow measures. Journal of Financial Statement Analysis, 4(1), 40-56. http://dx.doi.org/10.1016/0748-5751(86)90010-2

Bonnier, K.A., \& Bruner, R.F. (1989). An analysis of stock price reaction to management change in distressed firms. Journal of Accounting and Economics, 11, 95-106. http://dx.doi.org/10.1016/0165-4101(89)90015-3

Burks, J.T. (2010). Disciplinary measures in response to restatements after Sarbanes-Oxley. Journal of Accounting and Public Policy, 29, 195-225. http://dx.doi.org/10.1016/j.jaccpubpol.2010.03.002

Bushee, J. B., \& T. H. Goodman. (2007). Which institutional investors trade based on private information about earnings and returns? Journal of Accounting and Research, 45(2), 289-321. http://dx.doi.org/10.1111/j.1475-679X.2007.00235.x

Canadian Institute of Chartered Accountants (CICA). (2010). Environmental, Social, and Governance (ESG) Issues in Institutional Investor Decision Making. CICA, Toronto.

Cohen, J., L. Holder-Webb, L. Nath, \& D. Wood. (2011). Retail investors' perceptions of the decision-usefulness of economic performance, governance, and corporate social responsibility disclosures. Behavioral Research in Accounting, 23(1), 109-129. http://dx.doi.org/10.2308/bria.2011.23.1.109

Collins, D., Masli, A., Reitenga, A.L., \& Sanchez, J.M. (2009). Earnings restatements, the Sarbanes-Oxley Act and the disciplining of chief financial officers. Journal of Accounting, Auditing and Finance, 24, 1-34. http://dx.doi.org/10.2139/ssrn.1076800

Core, J. E. (2001). A review of the empirical disclosure literature: Discussion. Journal of Accounting and Economics, 31(1-3), 441-456. http://dx.doi.org/10.1016/S0165-4101(01)00036-2

Coughlan, A., \& Schmidt, R. (1985). Executive compensation, management turnover and firm performance: An empirical investigation. Journal of Accounting \& Economics, 7, 43-66. 
http://dx.doi.org/10.1016/0165-4101(85)90027-8

Cruise, S. (2011). Investors demand improved sustainability reporting.

Davis, A. K., Piger, J. M., \& Sedor, L. M. (2012). Beyond the numbers: Measuring the information content of earnings press release language. Contemporary Accounting Research, 29(3), 845-68. http://dx.doi.org/10.1111/j.1911-3846.2011.01130.x 1

Denis, D.J., Denis, D.K., \& Sarin, A. (1997). Ownership structure and top executive turnover. Journal of Financial Economics, 193-221. http://dx.doi.org/10.1016/S0304-405X(97)00016-0

Desai, H., Hogan, C., \& Wilkins, M.S. (2006). The reputational penalty for aggressive accounting: earnings restatements and management turnover. The Accounting Review, 81, 83-112. http://dx.doi.org/10.2308/accr.2006.81.1.83

Dhaliwal, D. S., O. Z. Li, A. Tsang, \& Y. G. Yang. (2011). Voluntary nonfinancial disclosure and the cost of equity capital: The initiation of corporate social responsibility reporting. The Accounting Review, 86(1), 59-100. http://dx.doi.org/10.2308/accr.00000005

Diamond, D., \& R. Verrecchia. (1991). Disclosure, liquidity, and the cost of capital. The Journal of Finance, 46(4), 1325-1359. http://dx.doi.org/10.2307/2328861

Engel, E., Hayes, R.M., \& Wang, X. (2003). CEO turnover and properties of accounting information. Journal of Accounting and Economics, 36, 197-226. http://dx.doi.org/10.1016/j.jacceco.2003.08.001

Foster, F. D., \& S. Viswanathan. (1993). The effect of public information and competition on trading volume and price volatility. Review of Financial Studies, 6(1), 23-56. http://dx.doi.org/10.1093/rfs/6.1.23

Furtado, E.P., \& Karen, V. (1990). Causes, consequences, and shareholder wealth effects of management turnover: A review of the empirical evidence. Financial Management, 19, 60-75. http://dx.doi.org/10.2307/3665635

Furtado, E.P., \& Rozeff, M.S. (1987). The wealth effects of company initiated management changes. Journal of Financial Economics, 18, 147-160. http://dx.doi.org/10.1016/0304-405X(87)90065-1

Galbraith, J. R. (1982) growth. The Journal of Business Strategy, 3(1), 70-79. http://dx.doi.org/10.1108/eb038958

Gelb, D. S., \& J. A. Strawser. (2001). Corporate social responsibility and financial disclosures: An alternative explanation for increased disclosure. Journal of Business Ethics, 33(1), 1-13. http://dx.doi.org/10.1007/s10551-008-9968-9

Hanks, S. H., C. J. Watson, E. Jansen, \& G. N. Chandler. (1993). Tightening the life-cycle construct: A taxonomic study of growth stage configurations in high-technology organizations. Entrepreneurship, Theory and Practice, 18(2), 5-30. 
Healy, P., \& K. Palepu. (2001). Information asymmetry, corporate disclosure, and the capital markets: A review of the empirical disclosure literature. Journal of Accounting and Economics, 31(1-3), 405-40. http://dx.doi.org/10.1016/S0165-4101(01)00018-0

Henry, E. (2008). Are investors influenced by how earnings press releases are written? $\begin{array}{llll}\text { Journal of } & \text { Business } & \text { Communication, } 407 .\end{array}$ http://dx.doi.org/10.1177/0021943608319388

Holthausen, R. W., \& R. E. Verrecchia. (1988). The effect of sequential information releases on the variance of price changes in an intertemporal multi-asset market. Journal of Accounting Research, 26(1), 82-106. http://dx.doi.org/10.2307/2491114

Iatridis, G., \& P. Alexakis. (2012). Evidence of voluntary accounting disclosures in the Athens Stock Market. Review of Accounting and Finance, 11(1), 73-92. http://dx.doi.org/10.1108/14757701211201830

Kaplan, S., \& Minton, B. (2006). How has CEO turnover changed? Increasingly performance sensitive boards and increasingly uneasy CEOs. Working Paper. National Bureau of Economic Research. http://dx.doi.org/10.2139/ssrn.891326

Karpoff, J.M., Lee, D.S., \& Martin, G.S. (2008). The Consequences to managers for financial misrepresentation. Journal of Financial Economics, 88, 193-217. http://dx.doi.org/10.1016/j.jfineco.2007.06.003

Kim, A. (2008). Effectiveness of the Sarbanes Oxley Action corporate governance: Evidence from executive turnover. Working Paper. University of Minnesota.

Kim, O., \& R. E. Verrecchia. (1991). Trading volume and price reactions to public announcements. Journal of Accounting Research, 29, 302-321. http://dx.doi.org/10.2307/2491051

Kravet, T., \& Muslu, V. (2013). Textual risk disclosures and investors' risk perceptions. $\begin{array}{lllll}\text { Review of Accounting 1088-1122. } & \text { Studies, } & 18(4), & 1088\end{array}$ http://dx.doi.org/10.1007/s11142-013-9228-9

Lambert, R., C. Leuz, \& R. Verrecchia. (2007). Accounting information, disclosure, and the cost of capital. Journal of Accounting Research, 45(2), 385-420. http://dx.doi.org/10.1111/j.1475-679X.2007.00238.x

Lev, B., C. Petrovits, \& S. Radhakrishnan. (2010). Is doing good good for you? Yes, charitable contributions enhance revenue growth. Strategic Management Journal, 31(2), 182-200. http://dx.doi.org/10.1002/smj.810

Loughran, T., \& Mcdonald, B. (2011). When is a liability not a liability? Textual analysis, dictionaries, and 10-Ks. The Journal of Finance, 66(1), 35-65. http://dx.doi.org/10.1111/j.1540-6261.2010.01625.x

Margolis, J., \& J. Walsh. (2001). People and profits: The search for a link between a company's social and financial performance. Rahway, NJ: Erlbaum Associates. 
Merkley, K. J. (2014). Narrative disclosure and earnings performance: Evidence from R\&D disclosures. Accounting Review, 89(2), 725-57. http://dx.doi.org/10.2308/accr-50649

Orlitzky, M., F. L. Schmidt, \& S. L. Rynes. (2003). Corporate social and financial performance: A meta-analysis. Organization Studies, 24(3), 403-441. http://dx.doi.org/10.1177/0170840603024003910

Price, S. M., J. S. Doran, D. R. Peterson, \& B. A. Bliss. (2012). Earnings conference calls and stock returns: The incremental informativeness of textual tone. Journal of Banking \& Finance, 36(4), 992-1011. http://dx.doi.org/10.1016/j.jbankfin.2011.10.013

Rodríguez, P., D. S. Siegel, A. Hillman, \& L. Eden. (2006). Three lenses on the multinational enterprise: Politics, corruption, and corporate social responsibility, Journal of International Business Studies, 37, 733-746. http://dx.doi.org/10.1057/palgrave.jibs. 8400229

Warner, J., Watts, R.L., \& Wruck, K.H. (1988). Stock prices and top management changes. Journal of Financial Economics, 461-492. http://dx.doi.org/10.1016/0304-405X(88)90054-2

Weisbach, M. (1988). Outside directors and CEO turnover. Journal of Financial Economics, 20, 431-460. http://dx.doi.org/10.1016/0304-405X(88)90053-0 